\title{
Pengaruh Pupuk Kandang dan NPK Mutiara terhadap Pertumbuhan dan Produksi Kacang Panjang (Vigna sinensis L.) pada Tanah Berpasir
}

\section{Effect of Manure and NPK Mutiara against The Growth and Production of Cowpea (Vigna sinensis L.) on Sandy Soil}

\author{
Atika Oktavianti ${ }^{1}$, Munifatul Izzati ${ }^{2}$, dan Sarjana Parman ${ }^{2}$ \\ ${ }^{1)}$ Program Studi Biologi, Departemen Biologi, Fakultas Sains dan Matematika, Universitas Diponegoro \\ ${ }^{2}$ Departemen Biologi, Fakultas Sains dan Matematika, Universitas Diponegoro \\ Jl. Prof. Soedarto, SH, Tembalang, Semarang \\ Email: atikaoktv31@gmail.com
}

\begin{abstract}
ABSTRAK
Kacang panjang (Vigna sinensis L.) sebagai sayuran yang sangat digemari masyarakat, mengandung vitamin dan mineral yang sangat tinggi, sehingga memiliki potensi yang besar untuk selalu dikembangkan. Pemanfaatan lahan pasir dapat digunakan untuk memperluas kegiatan budidaya kacang panjang, apabila diberi penambahan bahan organik di dalamnya. Penelitian ini bertujuan untuk mengetahui apakah penambahan pupuk kandang dan NPK Mutiara dapat meningkatkan pertumbuhan dan produksi serta apakah terdapat perbedaan pertumbuhan dan produksi kacang panjang (Vigna sinensis L.) pada tanah berpasir. Penelitian ini menggunakan Rancangan Acak Lengkap (RAL) dengan 3 perlakuan dan 9 kali ulangan. P0: kontrol (tanpa pupuk), P1: Pupuk kandang sapi $500 \mathrm{~g} /$ tanaman, dan P2: Pupuk NPK mutiara $1 \mathrm{~g} / \mathrm{L}$ atau setara dengan 125 $\mathrm{mL} /$ tanaman. Perlakuan kontrol, pupuk kandang dan NPK Mutiara pada parameter pertumbuhan lebih tinggi hasilnya oleh perlakuan pupuk NPK Mutiara yaitu berpengaruh pada tinggi tanaman namun tidak berpengaruh pada jumlah daun kacang panjang. Perlakuan kontrol, pupuk kandang dan NPK Mutiara pada parameter produksi lebih memiliki pengaruh oleh perlakuan pupuk NPK Mutiara yaitu berpengaruh pada hasil jumlah polong, panjang polong, berat basah tanaman, berat basah polong, berat kering tanaman, berat kering polong, dan berat kering biji namun tidak berpengaruh hasilnya pada jumlah bunga tanaman kacang panjang.
\end{abstract}

Kata kunci: kacang panjang, pupuk kandang, NPK Mutiara, tanah berpasir

\begin{abstract}
Cowpea (Vigna sinesis L.), as widely favourite vegetable, contains high vitamins and minerals, so that it is very potential to be grown. Cowpea cultivation on sandy soil may possibly be improved by adding organic materials into the soil. This research was conducted to determine whether the manure and the NPK Mutiara application on sandy soil could improve cowpea growth and production. This research used Completely Random Design (CRD) by 3 treatments and 9 repetitions. P0: control (without fertilizer), P1: Cow manure $500 \mathrm{~g} / \mathrm{plant}$, and P2: NPK Mutiara fertilizer $1 \mathrm{~g} / \mathrm{L}$ or equal to $125 \mathrm{~mL} / \mathrm{plant}$. The NPK Mutiara fertilizer application shows the highest effect on the height of the plants rather than control and cow manure application. But it is less affecting to the number of cowpea leaves. Regarding to production parameter, NPK Mutiara gives the best effect on the number, length, wet and dry weight of the pods, wet and dry weight of the plants, and wet and dry weight of the peas. But it does not affect to the numbers of cowpea flowers.
\end{abstract}

Keywords: Cowpea, manure, NPK Mutiara, sandy soil

\section{PENDAHULUAN}

Tanaman kacang panjang (Vigna sinensis L.) merupakan tanaman sayur jenis kacangkacangan yang banyak diusahakan di Indonesia. Tanaman kacang panjang bukan tanaman asli Indonesia, namun berasal dari negara India dan Afrika Tengah yang telah berabad-abad dibudidayakan di Indonesia. (Arinong, 2013). Sayur ini banyak mengandung vitamin A, vitamin $\mathrm{B}$, dan vitamin $\mathrm{C}$ terutama pada polong yang masih muda. Biji kacang panjang banyak mengandung lemak, protein, dan karbohidrat. Dengan demikian, komoditi ini merupakan sumber protein nabati yang cukup potensial Haryanto (2007). 
Berdasarkan data yang didapatkan dari Badan Pusat Statistik Republik Indonesia, produktivitas kacang panjang terus mengalami penurunan dari tahun 2012 hingga tahun 2015. Tahun 2012, yaitu 455,615 ton/ha, tahun 2013 turun menjadi 450,859 ton/ha, tahun 2014 sebanyak 450,727 ton/ha, dan pada tahun 2015 turun menjadi 395,524 ton/ha (Badan Pusat Statistik, 2016).

Penurunan produksi kacang panjang di Indonesia bisa disebabkan karena faktor lingkungan atau karena lahan budidaya yang semakin berkurang karena pertambahan jumlah penduduk yang semakin meningkat sehingga membutuhkan tempat tinggal yang lebih luas. Apabila salah satu faktor yang menyebabkan berkurangnya produksi kacang panjang disebabkan karena semakin sempitnya lahan pertanian, maka budidaya dapat dilakukan pada area tanah berpasir.

Tanah berpasir merupakan tanah hasil dari proses perombakan batuan, sedimen yang kemudian melalui proses pengangkutan air dan diendapkan di tempat yang lebih rendah seperti hilir sungai, daratan, cekungan, danau, pantai dan sebagainya (Anonim, 2003). Tanah berpasir pada umumnya kurang baik apabila digunakan untuk budidaya tanaman karena tidak memiliki unsur hara yang banyak serta daya menyimpan air juga rendah, namun apabila tanah berpasir di beri bahan penambah seperti pupuk maka akan dapat membantu mensuplai unsur hara di dalam tanah berpasir serta dapat meningkatkan kemampuan tanah dalam menyimpan air lebih banyak.

Pupuk yang ditambahkan dapat berupa pupuk organik maupun anorganik seperti pupuk kandang dan NPK Mutiara. Pupuk kandang memiliki beberapa kelebihan dibandingkan dengan pupuk kimia yaitu membantu menetralkan $\mathrm{pH}$ tanah, membantu menetralkan racun akibat adanya logam berat di dalam tanah, memperbaiki struktur tanah menjadi lebih gembur dan secara langsung meningkatkan ketersediaan air tanah, membantu penyerapan hara dari pupuk kimia yang ditambahkan (Marsono, 2001). Pupuk NPK mutiara (16:16:16) merupakan salah satu pupuk anorganik bersifat majemuk yang memiliki unsur hara makro N, $\mathrm{P}$, dan $\mathrm{K}$ masing-masing $16 \%$ (Fahmi, 2014).

Penelitian ini bertujuan mengetahui perbedaan pengaruh pupuk bagi pertumbuhan dan produksi tanaman kacang panjang (Vigna sinensis L), khususnya pupuk kandang sapi dan NPK Mutiara pada tanah pasir serta apakah tanah pasir dapat digunakan untuk budidaya dan dapat meningkatkan pertumbuhan dan produksi tanaman kacang panjang (Vigna sinensis L.).

\section{METODE PENELITIAN}

Penelitian dilaksanakan pada bulan Agustus sampai November 2016 di wilayah Genuk, Semarang, Jawa Tengah.

Rancangan percobaan penelitian ini menggunkan Rancangan Acak Lengkap (RAL) dengan 3 perlakuan dan 9 kali ulangan yang terdiri dari :

P0 : kontrol (tanpa pupuk)

P1 : Pupuk kandang sapi $500 \mathrm{~g} / \mathrm{tanaman}$

P2 : Pupuk NPK mutiara $1 \mathrm{~g} / \mathrm{L}$ atau setara dengan $125 \mathrm{~mL} /$ tanaman

Prosedur penelitian yang dilakukan dalam penelitian ini adalah : pemilihan biji, pengolahan media, penanaman, pemeliharaan tanaman, dan pemupukan.

Teknik pengumpulan data yang dilakukan adalah parameter pertumbuhan dan produksi. Parameter pertumbuhan yang berupa : tinggi tanaman dan jumlah daun, sedangkan parameter produksi berupa : jumlah bunga, jumlah polong, panjang polong, berat basah tanaman, berat basah polong, berat kering tanaman, berat kering polong, dan berat kering biji.

\section{HASIL DAN PEMBAHASAN}

\section{Tinggi Tanaman dan Jumlah Daun}

Perlakuan pupuk NPK Mutiara 1 g/L menghasilkan tinggi tanaman kacang panjang yang paling tinggi yaitu $322 \mathrm{~cm}$. Perlakuan tanpa pupuk (kontrol) mengalami penambahan tinggi tanaman yang paling rendah dibanding perlakuan menggunakan pupuk kandang sapi dan pupuk NPK Mutiara yaitu 282,6 cm.

Tinggi tanaman yang paling rendah adalah perlakuan kontrol, hal ini dapat disebabkan karena kandungan $\mathrm{N}$ pada perlakuan kontrol sangat sedikit dan tanah yang digunakan berupa tanah berpasir sehingga, tanah kurang mendapat suplai unsur hara $\mathrm{N}$ yang akan digunakan bagi tanaman. Oleh Hendri (2015), bahwa unsur hara N diperlukan oleh tanaman untuk pembentukan klorofil, dan merangsang pertumbuhan vegetatif tanaman seperti batang, cabang, dan daun.

Tinggi tanaman tertinggi dialami oleh tanaman akibat perlakuan menggunakan pupuk 
NPK hal ini terjadi karena tanaman yang diberi pupuk akan memliki kandungan unsur hara yang dapat membantu mempercepat pertumbuhan tanaman. diduga pupuk NPK dapat menyeimbangi kekurangan dari tanah berpasir yang memiliki kekurangan yaitu sangat minim unsur hara. Pertambahan tinggi tanaman dapat optimal karena pupuk NPK Mutiara sesuai dengan pendapat dari oleh Tarigan (2009), bahwa tanaman akan tumbuh dan menghasilkan secara optimal apabila ditanam di tempat yang memenuhi syarat tumbuhnya seperti faktor lingkungan yaitu faktor iklim seperti sifat tanah dan ketersediaan unsur hara.

Perlakuan pupuk kandang sapi terlihat tidak berbeda nyata dengan perlakuan tanpa pupuk (kontrol) yaitu 86,8 dengan 84,8. Pengaruh tidak berbeda nyata terjadi pula pada perlakuan menggunakan pupuk NPK Mutiara terhadap perlakuan tanpa pupuk (kontrol) yaitu 87,3 dengan
84,8. Hal ini tidak sesuai dengan pendapat Arniana (2012), bahwa semakin banyak pupuk atau dosis pupuk yang diberikan berarti akan semakin semakin banyak kadar hara yang dihasilkan dari hasil mineralisasi pupuk, yang dapat diserap oleh tanaman untuk meningkatkan pertumbuhan dan hasil tanaman kacang panjang.

Unsur hara $\mathrm{N}$ sangat penting untuk masa pembentukan daun yaitu pembentukan sel-sel baru dan pemanjangan sel pada sel meristem apikal tanaman kacang panjang. Pupuk NPK dapat diserap baik oleh tanaman karena dapat dilarutkan di dalam air sehingga lebih mudah untuk diserap tanaman karena tidak berbentuk padatan lagi. Hal ini sesuai dengan yang ditulis oleh Agromedia (2007) bahwa, pupuk anorganik memiliki beberapa keutamaan yaitu unsur hara yang tinggi, kemampuan menyerap air tinggi dan mudah larut sehingga mudah diserap oleh akar tanaman.

Tabel 1. Pertumbuhan kacang panjang pada perlakuan pupuk kandang dan NPK

\begin{tabular}{cccc}
\hline $\begin{array}{c}\text { Parameter } \\
\text { Pertumbuhan }\end{array}$ & $\begin{array}{c}\text { Kontrol } \\
\text { (tanpa pupuk) }\end{array}$ & $\begin{array}{c}\text { P1 } \\
\text { (pupuk kandang) }\end{array}$ & $\begin{array}{c}\text { P2 } \\
\text { (pupuk NPK) }\end{array}$ \\
\hline Tinggi Tanaman $(\mathrm{cm})$ & $282,6^{\mathrm{a}}$ & $311,5^{\mathrm{b}}$ & $322^{\mathrm{b}}$ \\
Jumlah Daun (helai) & $84,8^{\mathrm{a}}$ & $86,8^{\mathrm{a}}$ & $87,3^{\mathrm{a}}$ \\
\hline
\end{tabular}

Keterangan : Angka yang diikuti oleh huruf yang sama pada satu baris adalah hasil berbeda tidak nyata pada uji Duncan $\alpha=0.05$

Tabel 2. Produksi kacang panjang pada perlakuan pupuk kandang dan NPK

\begin{tabular}{lccc}
\hline Parameter Produksi & $\begin{array}{c}\text { Kontrol } \\
\text { (tanpa pupuk) }\end{array}$ & $\begin{array}{c}\text { P0 } \\
\text { (pupuk kandang) }\end{array}$ & $\begin{array}{c}\text { P2 } \\
\text { (pupuk NPK) }\end{array}$ \\
\hline Jumlah Bunga & $11,4^{\mathrm{a}}$ & $11,8^{\mathrm{a}}$ & $12,1^{\mathrm{a}}$ \\
Jumlah Polong & $5,2^{\mathrm{a}}$ & $5,7^{\mathrm{a}}$ & $6,3^{\mathrm{b}}$ \\
Panjang Polong & $25,5^{\mathrm{a}}$ & $35,1^{\mathrm{b}}$ & $41,1^{\mathrm{c}}$ \\
Berat Basah Tanaman & $143,2^{\mathrm{a}}$ & $152,1^{\mathrm{b}}$ & $158,9^{\mathrm{c}}$ \\
Berat Basah Polong & $39,9^{\mathrm{a}}$ & $44,3^{\mathrm{b}}$ & $49,8^{\mathrm{c}}$ \\
Berat Kering Tanaman & $4,6^{\mathrm{a}}$ & $4,7^{\mathrm{a}}$ & $7,7^{\mathrm{b}}$ \\
Berat Kering Polong & $1,4^{\mathrm{a}}$ & $1,9^{\mathrm{b}}$ & $2,4^{\mathrm{c}}$ \\
Berat Kering Biji & $0,04^{\mathrm{a}}$ & $0,05^{\mathrm{b}}$ & $0,05^{\mathrm{b}}$ \\
\hline
\end{tabular}

Keterangan : Angka yang diikuti oleh huruf yang sama pada satu baris adalah hasil berbeda tidak nyata pada uji Duncan $\alpha=0.05$ 
Jumlah bunga tanaman kacang panjang umur 10 minggu

Masing-masing hasil pada umur 10 minggu pemberian pupuk kandang sapi rata-rata menghasilkan jumlah bunga 11,8 , rata-rata jumlah bunga perlakuan pupuk NPK Mutiara sebanyak 12,1 sedangkan perlakuan kontrol menghasilkan rata-rata jumlah bunga sebanyak 11,4.

Menurut Susetyo (1985), dalam Nur (2011), berpendapat bahwa NPK mengandung beberapa unsur seperti $\mathrm{N}$ yang membantu membangun protoplasma untuk membentuk organ-organ tanaman, unsur $\mathrm{P}$ berfungsi untuk pertumbuhan akar maupun pembentukan pada bagian atas pada tanaman seperti batang dan daun, merangsang pembentukan bunga dan kemasakan buah.

\section{Jumlah polong tanaman kacang panjang umur 10 minggu}

Jumlah polong kacang panjang tertinggi dihasilkan oleh tanaman dengan perlakuan menggunakan pupuk NPK Mutiara yaitu sekitar 6,3 per tanaman dan hasil terendah dihasilkan oleh tanaman yang diberi perlakuan tanpa pupuk (kontrol) yaitu rata-rata hasil jumlah polong sebanyak 5,2 pertanaman.

Perlakuan menggunakan pupuk NPK Mutiara terhadap jumlah polong yang dihasilkan lebih tinggi. Menurut Sutedjo (2010), bahwa N berperan dalam pertumbuhan vegetatif tanaman, apabila unsur $\mathrm{N}$ semakin banyak maka dapat mempercepat proses sinteis karbohidrat, sedangkan unsur $\mathrm{P}$ berperan dalam pembentukan bunga dan buah tanaman, dan unsur $\mathrm{K}$ dapat meningkatkan kualitas buah pada tanaman.

\section{Panjang polong tanaman kacang panjang umur 10 minggu}

Hasil Uji ANOVA (Analysis of Variance) pada taraf signifikasi 95\% menunjukkan bahwa respon tanaman kacang panjang dengan perlakuan pupuk kandang dan pupuk NPK Mutiara terhadap panjang polong berbeda nyata.

Hasil di atas terlihat bahwa perlakuan menggunakan pupuk anorganik memberikan hasil produksi polong yang paling panjang diantara perlakuan pupuk organik kandang sapi dan perlakuan tanpa pupuk (kontrol). Kelebihan pupuk anorganik dibandingkan pupuk organik ialah kandungan unsur hara yang lebih tinggi dan lebih mudah larut dalam air sehingga unsur hara di dalamnya lebih tersedia bagi tanaman, sehingga tanaman lebih mudah melangsungkan pertumbuhan organ vegetatifnya secara optimal. (Kurniawati, 2008). Unsur P diperlukan untuk mempergiat pembentukan polong, mengurangi jumlah polong yang tidak berisi, dan untuk mempercepat kematangan polong (Oktavia, 2000).

\section{Berat basah tanaman kacang panjang umur 10 minggu}

Hasil berbeda nyata terlihat dari uji Duncan dengan hasil $\mathrm{P} 2$ rata-rata 158,8678 gram dan hasil P1 yaitu 152,1200 gram. Hasil P1 dan P2 masingmasing berbeda nyata dengan perlakuan P1 (kontrol) dengan rata-rata sekitar 143,1778 gram.

Hasil berat basah tanaman paling tinggi akibat perlakuan pupuk NPK lebih tinggi dibandingkan pupuk kandang, yang seharusnya pupuk kandang memiliki pengaruh lebih besar dibandingkan pupuk NPK karena pupuk kandang pada dasarnya dapat membantu tanah untuk menyimpan air lebih banyak, seperti yang dikemukakan oleh Makinde (2011) bahwa, pupuk organik memperbaiki material penyusun tanah dan memperbaiki kemampuan tanah dalam mengikat air.

\section{Berat basah polong tanaman kacang panjang umur 10 minggu}

Hasil tertinggi terjadi pada perlakuan menggunakan pupuk NPK Mutiara, sedangkan hasil terendah terjadi pada perlakuan tanpa pupuk (kontrol). Jumlah berat basah polong kacang pajang menunjukkan bahwa tanaman yang dipupuk menggunakan pupuk anorganik lebih memberikan pengaruh terhadap kuantitas polong tanaman kacang panjang, hal ini bisa terjadi karena kandungan yang lengkap dimiliki oleh pupuk NPK Mutiara dengan unsur N, P, dan K masing-masing sebanyak $16 \%$ dan dosis yang diberikan mencukupi untuk pertumbuhan dan produksi kacang panjang, seperti pendapat dari Rinsema 
(1986) dalam Pardono (2009), bahwa apabila macam, dosis, waktu pemberian dan cara pemberiannya tepat dapat mendorong pertumbuhan dan peningkatan hasil tanaman baik dari segi kualitas maupun kuantitasnya.

\section{Berat kering tanaman kacang panjang umur 10 minggu}

Perlakuan pemberian pupuk NPK Mutiara pada tanaman kacang panjang berpengaruh nyata terhadap berat kering tanaman yaitu sekitar 7,7 g, dan hasil terendah ditunjukkan oleh tanaman yang tidak diberikan perlakuan pupuk (kontrol) dengan berat kering tanaman sekitar 4,6 g. Hal ini dapat disebabkan karena tanaman perlakuan P2 lebih banyak memiliki kandungan air hasil penyerapan dari dalam tanah sehingga mengakibatkan hasil berat kering tanaman menjadi lebih tinggi. Menurut Sitompul (1995) (dalam Rachmadani (2014) tentang pengaruh pupuk organik dan anorgnik terhadap pertumbuhan buncis, bahwa perlakuan taraf pemupukan tidak menyebabkan perbedaan penyerapan air dan penimbunan hasil fotosintesis. Bobot basah dipengaruhi oleh kandungan air pada sel-sel tanaman yang kadarnya dipengaruhi oleh lingkungan seperti suhu dan kelembaban udara, sedangkan bobot kering tanaman yang tidak berbeda nyata menunjukkan adanya akumulasi senyawa organik yang berhasil disintesis tanaman antar perlakuan adalah sama.

\section{Berat kering polong kacang panjang umur 10 minggu}

Terdapat perbedaan secara nyata perlakuan pupuk kandang sapi terhadap perlakuan tanpa pupuk (kontrol), dan pengaruh berbeda nyata juga ditunjukkan oleh tanaman yang diberi perlakuan pupuk NPK Mutiara terhadap perlakuan kontrol. Perbedaan masing-masing hasil berat kering polong ini terjadi karena perbedaan aktivitas penyerapan yang dilakukan oleh masing-masing tanaman. Pupuk organik kandang sapi yang memiliki sifat dapat memperbaiki sifat biologi dan fisik tanah dapat membantu kegiatan akar dalam melakukan pengangkutan air ke dalam tanaman. Keunggulan pupuk kandang sapi bagi tanah yaitu dapat meningkatkan porositas tanah untuk menahan air dan oksigen yang lebih banyak. Karena adanya kemampuan untuk menahan air maka akar tanaman dapat lebih mudah dan lebih banyak menyerap air yang berpengaruh pada bobot basah dan kering polong kacang panjang (Kartasaputro, 1998).

\section{Berat kering biji kacang panjang umur 10 minggu}

Respon tanaman kacang panjang dengan perlakuan pupuk kandang dan pupuk NPK Mutiara terhadap berat kering biji tanaman kacang panjang berbeda nyata. Berat kering biji yang dipengaruhi juga oleh hasil fotosintat pada saat proses fotosintesis, dipicu pula oleh kandungan $\mathrm{K}$ (kalium) yang terdapat di dalam pupuk kandang serta di dalam NPK Mutiara. Menurut Hasbi, (2015) bahwa unsur kalium merupakan unsur kedua terbesar setelah $\mathrm{N}$ (Nitrogen). Kalium apabila terserap oleh akar tanaman dapat membantu mengaktifkan enzim-enzim dalam proses pembentukan ATP yang nantinya akan mentranslokasi gula pada bagian-bagian tanaman termasuk pada biji. Unsur kalium ini berfungsi untuk membantu dalam pengisian polong sehingga hasil biji dalam polong dapat terisi penuh supaya tidak kosong.

\section{KESIMPULAN}

Penambahan pupuk kandang dan NPK Mutiara dapat meningkatkan pertumbuhan dan produksi tanaman kacang panjang pada tanah berpasir dibandingkan dengan kontrol. Pupuk NPK Mutiara memberikan pengaruh yang nyata dan lebih tinggi pengaruhnya terhadap pertumbuhan dan produksi kacang panjang dibandingkan perlakuan menggunakan pupuk kandang, serta terdapat perbedaan hasil pertumbuhan dan produksi kacang panjang akibat perlakuan pupuk kandang dan pupuk NPK Mutiara, namun akan lebih baik apabila pupuk kandang dan NPK Mutiara dikombinasikan dengan dosis yang tepat.

\section{DAFTAR PUSTAKA}

Agromedia, R. 2007. Petunjuk Pemupukan. Agromedia Pustaka. Jakarta. 
Arinong, R. A. 2013. Aplikasi Pupuk Organik dan Umur Pemangkasan terhadap Pertumbuhan dan Produksi Tanaman Kacang Panjang (Vigna sinensis L.).

Arniana, A. 2012. Pemanfaatan Residu Bahan Organik dan Fosfor untuk Budidaya Tanaman Kacang Panjang (Vigna sinensis L.). berkala Penelitian Argonomi Vol 1: 815 .

Fahmi, N. 2014. Pengaruh Pupuk Organik dan Anorganik terhadap Pertumbuhan dan Hasil Kedelai (Glycine max (L.) merril). J. Floratek 9: 53-62.

Haryanto, E., T. Suhartini, dan E. Rahayu. 2007.Budidaya Kacang Panjang. Penebar Swadaya.Jakarta. 69 hal.

Hasbi, N. 2015. PengaruhPemberian Pupuk Nitrogen, Fosfor, dan Kalium terhadap Pertumbuhan dan Produksi Rumput Benggala (Panicum maximum). Skripsi. Fakultas Peternakan. Universitas Hasanuddin. Semarang.

Hendri, M. 2015. Pengaruh Pupuk Kandang Sapi dan Pupuk MPK Mutiara terhadap Pertumbuhan dan Hasil Tanaman Terung Ungu (Solanum melongena L.). Jurnal Agrivor Vol 14 (2).

Kartasaputro, A, G. 1998. Teknologi Budidaya Tanaman Pangan di Daerah Tropik. Bumi Aksara. Jakarta.

Makinde, E, A. 2011. Effects of Organik, Organomineral and NPK Fertilizer Treatments on The Nutrient Uptake of Amaranthus Cruentus (L) on Two Soil Types in Lagos, Nigeria. Journal of Central European Agriculture vol 12 (1).

Marsono dan Sigit. 2001. Pupuk Akar, Jenis, dan Aplikasi. Penebar Swadaya. Jakarta.

Pardono. 2009. Pengaruh Pupuk Organik Air Kencing Sapi dan Pupuk Kandang terhadap Pertumbuhan dan Hasil Kacang Panjang (Vigna sinensis L.). Jurnal Agrosains Vol 11 (1).
Rachmadani, N. W. 2014. Pengaruh Pupuk Organik dan Anorganik terhadap Pertumbuhan dan Hasil Tanaman Buncis Tegak (Phaseolus vulgaris L.). Jurnal Produksi Tanaman Vol 2 (6).

Sutedjo, Mulyani M. 2010. Pupuk Dan Cara Pemupukan. Rineka Cipta. Jakarta.

Tarigan, K. 2009. Pengaruh pupuk terhadap Optimasi Produksi Tanaman. Universitas Sumatra Utara, Medan. 